Tjalling C. Koopmans Research Institute Tplligh Aoopman

Discussion Paper Series nr: 09-16

\title{
Competition and Innovation: Evidence from Financial Services
}

Jaap W.B. Bos James W. Kolari

Ryan C.R. van Lamoen 


\section{Tjalling C. Koopmans Research Institute Utrecht School of Economics \\ Utrecht University}

Janskerkhof 12

3512 BL Utrecht

The Netherlands

telephone $\quad+31302539800$

fax +31302537373

website www.koopmansinstitute.uu.nl

The Tjalling C. Koopmans Institute is the research institute and research school of Utrecht School of Economics.

It was founded in 2003, and named after Professor Tjalling C. Koopmans, Dutch-born Nobel Prize laureate in economics of 1975.

In the discussion papers series the Koopmans Institute publishes results of ongoing research for early dissemination of research results, and to enhance discussion with colleagues.

Please send any comments and suggestions on the Koopmans institute, or this series to J.M.vanDort@uu.nl

ontwerp voorblad: WRIK Utrecht

\section{How to reach the authors}

Please direct all correspondence to the first author.

Jaap W.B. Bos

Ryan C.R. van Lamoen

Utrecht University

Utrecht School of Economics

Janskerkhof 12

3512 BL Utrecht

The Netherlands.

E-mail: J.W.B.Bos@uu.nl

James W. Kolari

R.vanlamoen@uu.nl

Mays Business School

Texas A\&M University

310R Wehner Building

4218 TAMU, College Station

Texas, 77843-4218, USA

E-mail: j-kolari@tamu.edu 


\title{
Competition and Innovation: Evidence from Financial Services
}

\author{
Jaap W.B. Bosa \\ James W. Kolari \\ Ryan C.R. van Lamoen ${ }^{a}$ \\ aUtrecht School of Economics \\ Utrecht University \\ ${ }^{b}$ Mays Business School \\ Texas, U.S.A
}

Juni 2009

\begin{abstract}
In this paper we seek to contribute to the literature on competition and innovation by focusing on individual firms within the U.S. banking industry in the period 1984-2004. We measure innovation by estimating technology gaps and find evidence of an inverted- $U$ relationship between competition and the technology gaps in banking. This finding is robust over several different specifications and is consistent with theoretical and empirical work by Aghion, Bloom, Blundell, Griffith, and Howitt (2005b). The optimal amount of innovation requires a slightly positive mark up. Also, we find that the U.S. banking industry as a whole has consolidated beyond this optimal innovation level and that state-level interstate banking deregulation has lowered innovation.
\end{abstract}

Keywords: competition, innovation, stochastic frontier analysis, technology gap ratio, banking

JEL classification: D21, G21, L10, O30

\section{Acknowledgements}

We thank Rob Alessie, Claire Economidou, Luis Orea, Mark Sanders, participants at the 2008 North American ProductivityWorkshop at New York University, and seminar participants at Utrecht School of Economics for helpful comments, as well as the Center for International Business Studies at Texas A\&M University for financial support. The usual disclaimer applies. 


\section{Introduction}

Seminal work by Schumpeter (1942) posits that product market competition discourages innovation by diminishing monopoly rents. By contrast, Aghion, Harris, Howitt, and Vickers (2001) assert that competition may foster innovation as firms attempt to escape competition. ${ }^{1}$ Supporting this conjecture, some empirical studies find an invertedU pattern between competition and innovation (e.g., Scherer, 1967; Levin and Mowrey, 1985). In an attempt to reconcile theory and evidence, Aghion and Griffith (2005) and Aghion, Bloom, Blundell, Griffith, and Howitt (2005b) propose a theoretical model that is able to explain an inverted-U relationship between competition and innovation, wherein an escape competition effect initially dominates until competition reaches a sufficient level at which the rent dissipation effect thereafter prevails. ${ }^{2}$

The present paper contributes to the competition/innovation literature in the following ways. First, we extend this literature from the manufacturing sector to the (financial) services sector. Because a well-functioning financial sector is crucial to the economy, it is important to understand its innovation dynamics. Second, we introduce a new innovation measure. Instead of using traditional innovation outputs (e.g., patents which are mostly relevant to manufacturing), we focus on banks' ability to minimize costs through innovations. Following earlier work by Hayami and Ruttan (1970), Mundlak and Hellinghausen (1982), and Lau and Yotopoulos (1989), we estimate and envelope annual minimum cost frontiers to create a metafrontier. The distance to the metafrontier constitutes each bank's technology gap, which is closed if the bank manages to innovate. Third, our innovation measure enables us to derive and estimate the model of Aghion et al. (2005b) at the firm-level for a single industry experiencing historic structural and competitive changes during our sample period. By focusing on a single industry, we avoid the assumption that the competition/innovation relationship is the same across industries. Fourth, our empirical analyses provide detailed evidence on the effects of interstate banking deregulation aimed at increasing competition in financial services. Fifth, and last, we examine the impact of bank consolidation on their innovation behavior.

Driven by globalization, technological change, deregulation, and other forces, the U.S. banking industry has experienced dramatic changes in structure and competition (Jones and Critchfield, 2005). From 1984 to 2004, the industry consolidated from over 14,000 banks to around 7,500 banks (Berger, Kashyap, and Scalise, 1995; Berger, Demsetz, and Strahan, 1999). Concomitantly, the average size of banks grew as banks with assets totaling more than $\$ 10$ billion increased their share of industry assets from 30 percent to over 70 percent (Rhoades, 2000). ${ }^{3}$ A major concern is that continuing consolidation will result in less competition. For example, Cetorelli and Strahan (2006) find that, in banking markets that are highly concentrated, nonfinancial firms have significantly less access to credit. On the positive side, financial development is believed to foster efficient allocation of capital, improved risk sharing, and possibly a higher savings rate

\footnotetext{
1 See literature reviews by Kamien and Schwartz (1982) and Symeonidis (1996).

2 The model is also able to explain positive or negative effects of competition on innovation. Their empirical evidence for manufacturing industries in the U.K. tends to support the hypothesis of an inverted-U pattern.

3 Similar consolidation trends have occurred in the European Union, United Kingdom, Japan, and other countries around the world (Carletti et al., 2007).
} 
that can boost economic growth (Pagano, 1993; Levine, 2004). Empirical studies confirm the importance of financial development in enhancing growth (Levine et al., 2000; Levine and Zervos, 1998; Levine, 1997; King and Levine, 1993). Relevant to our purpose, innovations in the banking sector are an important channel through which financial development affects economic growth (Frame and White, 2004).

Consistent with Aghion and Griffith (2005), based on a large sample of U.S. banks from the sample period 1984-2004, we find evidence of an inverted-U relationship between competition and technology gaps in banking. This finding is robust over several different specifications and supports theoretical and empirical work by Aghion et al. (2005b). The optimal amount of innovation requires a slightly positive markup. Exploring further, we find that the U.S. banking industry as a whole has consolidated beyond this optimal innovation level and that interstate banking deregulation has lowered innovation through its effect on competition.

Section 2 provides a brief overview of studies on financial innovation in the U.S. banking industry. Section 3 describes the theoretical model developed by Aghion et al. (2005b) to explain the inverted-U pattern. Section 4 overviews the data and methodology. Section 5 empirically investigates the existence of an inverted-U relationship, discusses model robustness, examines the impact of interstate banking deregulation, and considers whether the consolidation process has gone too far. Section 6 concludes.

\section{Financial innovation in the U.S. banking industry}

Deregulation of prices, products, and geographic restrictions on permissible banking activities over the past 25 years has increased the contribution of market forces to financial innovation in the banking industry. In this regard, Vives (2001) observes that deregulation and financial innovations, including advances in information technology, management techniques, and risk adjustment (e.g., derivatives, securitization, and offbalance sheet activities), have substantially increased competition in U.S. and European banking markets.

Frame and White (2004) comprehensively survey the literature on financial innovation by identifying 39 empirical studies. ${ }^{4}$ They define financial innovation as comprising activities that internally reduce bank costs and risks or externally better meet the convenience and needs of customers. ${ }^{5}$ They broadly group financial innovations into new products (e.g., automated teller machines or ATMs, credit and debit cards, adjustable-rate mortgages, etc.), new production processes (e.g., electronic payments and record keeping, information gathering and dissemination via computers and

\footnotetext{
4 By comparison, the second largest empirical literature in the field of industrial organization (IO) is innovation. Some of the reasons offered for this large difference in empirical research include: financial services are normally not included in research and development $(R \& D)$ budgets, patents on financial services are rare, data in banking accounting statements on innovation is limited, IO-trained economists are not knowledgeable of the financial services sector, and few financial economist are well trained in IO and Schumpeterian hypotheses. Here we seek to bridge the gap to some extent between IO economists and finance/banking economists by empirically testing the relationship between competition and innovation in the U.S. banking industry.

5 Van Horne (1985) more broadly defines financial innovation as making markets more operationally efficient or complete (i.e., the number and types of securities span all possible return and risk contingencies or states of the world demanded by market participants). Also, Allen and Gale (1994) propose that financial innovation is associated with efficient risk sharing due to the completion of markets.
} 
telecommunications, automated credit scoring models, securitization of loans, crossselling financial services, etc.) and new organizational forms (e.g., internet-only banks, interstate banking, diversified banks with traditional and nontraditional financial services, etc.). The practical significance of these financial innovations lies in their contribution to enhancing financial intermediation, which allocates savings to investment and thereby contributes to economic growth (see King and Levine (1993) and Levine (1997)).

Summarizing the literature, Frame and White (2004) conclude that the following factors tend to increase innovation in financial services: regulation ${ }^{6}$, institution size ${ }^{7}$, higher individual education and income ${ }^{8}$, as well as first-mover, cost, and reputational advantages. ${ }^{9}$ Frame and White (2004) also cite other papers on securities, process, and organizational innovations, as well as the welfare effects of financial innovations. They conclude that, given the important role of financial innovation in the financial system and the economy as a whole, there is considerable room for future research in this "relatively untilled field."

A separate branch of the banking literature examines technical change in the context of cost and profit efficiency analyses of financial institutions. In this regard, Van Horne (1985) observes that financial innovations are motivated by operational inefficiencies. Less efficient financial institutions are less competitive and, therefore, less likely to survive. Importantly, as Ross (1989) points out, institutions are the major agents of innovation in financial markets. In general, the efficiency literature tends to support the institution size effect in financial innovation studies cited above. Elyasiani and Mehdian (1990) and Hunter and Timme (1991) find that larger banks experienced greater cost efficiency gains compared to small banks in the 1980s. ${ }^{10}$ Humphrey (1993) finds that large banks had more technical change than small banks in the late 1970s. Also, Berger and Mester (1997) find that while large banks had decreasing cost efficiency over time, they exhibited increasing profit efficiency compared to small banks in the 1980s and 1990s. ${ }^{11}$ Consistent with these studies, Wheelock and Wilson (1999) report greater technological gains among large banks in the 1980s and 1990s, which leads them to conclude that competitive and regulatory changes in the banking industry have benefited larger over smaller banks. Lastly, Altunbas, Goddard, and Molyneux (1999) find that larger banks in 15 European countries experienced larger gains from technical change than smaller banks in the period 1989-1996.

\footnotetext{
6 Lerner (2002) finds that changes in regulation motivate institutions to innovate new financial services and instruments in an attempt to gain a competitive advantage. See also Ben-Horim and Silber (1977), Miller (1986) Molyneux and Shamoukh (1996), and White (2000).

7 Size is repeatedly found to be linked to the likelihood of different financial innovations (e.g., see internet banking studies by Pennings and Harianto (1992), Sullivan (2000), Furst et al. (2002), and Nickerson and Sullivan (2003)). Also, with respect to small business credit scoring, Frame et al. (2001), Chourchane et al. (2002), Akhavein et al. (2005), and Berger et al. (2005) find a link between institution size and innovation. ATM studies by Hannan and McDowell (1984), Ingham and Thompson (1993), Saloner and Shepard (1995), and Gourlay and Pentecost (2002) again find a size effect.

8 See, for example, Carow and Staten (1999), Mantel (2000), and Mantel and McHugh (2001).

9 See Tufano (1989), Carow (1999b), and Carow (1999a).

${ }^{10}$ However, Hunter and Timme (1991) do not find significant differences between large and small banks in terms of technical change.

${ }^{11}$ Similarly, Berger and Mester (2003) report decreasing cost productivity but increasing profit productivity among U.S. banks in the period 1991-1997.
} 
While the above studies find that institution size is positively related to financial innovation in line with Schumpeter's hypothesis, few studies have attempted to link financial innovation and competition. Based on a sample of about 3,800 U.S. commercial banks in the period 1971-1979, Hannan and McDowell (1984) report evidence that the likelihood of ATM adoption is positively related to bank size, market concentration (i.e., three-firm concentration ratios in SMSAs or counties), and membership in a bank holding company. They infer that Schumpeter's hypothesis is supported by these empirical results. Chourchane, Nickerson, and Sullivan (2002) employ both simple bivariate and multivariate logit analyses to examine the competitive effects of internet banking for about 1,600 U.S. commercial banks in 1999. Unlike Hannan and McDowell, they find that the market concentration of competitive rivals lowers the likelihood of banks entering internet banking markets. Also, faced with uncertain demand, larger banks are more likely to enter internet banking than smaller banks, who prefer to delay their investment decision until larger banks have committed assets to the technological change. Another study by Mantel and McHugh (2001) considers the question of whether, given regulatory oversight of consumer protection issues, there is sufficient competition and innovation in consumer electronic payments, including credit cards, debit cards, e-cash, and smart cards. They conclude that private sector efforts to achieve adequate consumer safety are as effective as regulatory intervention. Also, financial innovation in electronic consumer payments would increase to a greater extent due to market forces compared to regulation. Finally, Akhavein, Frame, and White (2005) test for the impact of market competition on the adoption of small business credit scoring for a sample of 96 large U.S. banks in 1997. Like prior studies, bank organization size is positively related to earlier adoption of credit scoring methods. However, market concentration as measured by an average Herfindahl-Hirschman index (HHI) across local geographic markets is not significant. Overall, these studies yield mixed evidence on the link between competition and innovation but confirm larger banks are innovation leaders.

Other studies posit a variety of theoretical predictions concerning innovation and financial services. Van Horne (1985) conjectures that uncertainty about regulations, tax laws, inflation, international events, and technology will lead to a continuing stream of financial innovations. Boot and Thakor (1997) theorize that a universal banking system comprised of joint commercial and investment banks will produce less innovation than functionally-separated financial institutions due to adverse spillover effects of (for example) securities innovations on commercial banking profits. However, they argue that in mixed financial systems with both universal and functionally-separate institutions, large universal banks will have a competitive advantage to influence changes in regulations that favor financial innovations in which scope economies are required. ${ }^{12}$

Related work by Bhattacharyya and Nanda (2000) theorizes that larger investment banks will be more likely to innovate new financial services due to larger market shares with greater revenue incentives. Smaller banks have less incentive to innovate but are expected to be more aggressive than large banks in their introduction strategy (e.g., attracting large bank customers). Another study by Hauswald and Marquez (2003) theoretically proposes that financial innovation in information processing and dissemination can change competition in the banking industry (see also Wilhelm (2001)). Advances in

\footnotetext{
12 The stakeholder capture theory proposes that some agents can sway public policy decisions in their favor (e.g., see Kroszner and Strahan (1999)).
} 
information technology that improve information processing capabilities of banks will tend to decrease competition as some banks gain an information advantage over other banks. On the other hand, if information dissemination is increased by information technology innovations, competition will increase due to widespread access to proprietary information that levels the playing field. They conclude that the relative importance of these two information effects is an empirical question.

In sum, consistent with empirical studies cited above, different theories predict a variety of competition/innovation relationships for financial services, in addition to a greater likelihood of financial innovation by larger institutions.

\section{The Model}

This section applies the model developed by Aghion et al. (2005b) to the banking industry. The model is used to derive the "escape competition effect" (positive effect of competition on innovation) and the "Schumpeterian effect" (negative effect of competition on innovation) and subsequently explain how the balance between these effects generates an inverted-U relationship. While Aghion et al. model an economy and derive the average flow of innovations for intermediate sectors, we apply their model to the banking industry and derive the average flow of innovations for a firm in a geographical banking market. Since their model is well-known, we only provide a brief description of our banking industry application.

The Aghion et al. model assumes that there is a continuum (with total mass equal to one) of identical consumers in the economy that use a constant intertemporal discount rate $r$ and have the utility function $u\left(y_{t}\right)=\ln y_{t}$. Here we extend their model to the banking industry. The consumption good of banking institutions $\left(y_{t}\right)$ is financial services produced using input services from a continuum of intermediate sectors in the production function $\ln y_{t}=\int_{0}^{1} \ln x_{j t} d j$, where $x_{j t}$ is an aggregate of two intermediate goods $A$ and $B$ produced by two banks (duopoly) in sector $j$. In our model each intermediate sector represents a geographical (e.g., local) banking market. ${ }^{13}$ The subutility function is defined as $x_{j}=x_{A j}+x_{B j}$. Consumers maximize the subutility function with respect to their (normalized) budget constraint. ${ }^{14}$

Banks only use labor as an input at the (exogenous) normalized wage rate $w(t)=1$, and it is assumed that the production function exhibits constant returns. The unit cost of production is independent of the quantity produced, such that the unit cost structure becomes $c_{i}=\gamma^{-k_{i}}$, where $\gamma^{-k_{i}}$ is the unit labor requirement of bank $i, \gamma$ is the size of an innovation (assumed to be larger than one), and $k_{i}$ is the technological level of a bank. Hence, innovations lower the unit cost due to decreasing the required units of labor per unit of output. The relative costs of a bank depend only on the technological gap. The maximum technological gap in a sector is assumed to be one $(m=1)$, and technological advances occur through step-by-step innovations instead of leapfrogging

\footnotetext{
${ }^{13}$ Competition in banking occurs at a local level for many products and services (e.g., see Pilloff (1999) and Berger et al. (1999)).

${ }^{14}$ The income of consumers is normalized to unity by using the expenditure as the numeraire for prices in each period.
} 
models. ${ }^{15}$ The R\&D cost function $\psi(n)=n^{2} / 2$ is expressed in units of labor $n$. Furthermore, a Poisson process for innovations is assumed and leaders or neck-and-neck banks move one technological step ahead with a Poisson hazard rate of $n$ (R\&D intensity) by spending $\psi(n)$ on R\&D. The laggard bank moves ahead with the hazard rate $n+h$ if it puts effort into R\&D, where $h$ is a help factor that represents R\&D spillovers or the ability to copy the technology of a leader. The R\&D intensities of leading banks, laggard banks, and neck-and-neck banks are $n_{1}, n_{-1}$, and $n_{0}$, respectively. By assumption, leaders do not innovate $\left(n_{1}=0\right)$, as laggard banks can copy their previous technology immediately (so that the maximum gap remains one).

Product market competition is modeled by the ability of banks to collude. It is assumed that banks are able to collude if they are operating in a leveled bank market segment but cannot collude if the bank market segment is unleveled. It is important to note that multi-market contact may facilitate collusive behavior. ${ }^{16}$ We assume that a bank may face another bank in several markets, but it does not face the same bank in all markets. Furthermore, it is assumed that a bank facing one competitor in several markets has the same technology gap in these markets. ${ }^{17}$ The profits of laggard banks and leaders are $\pi_{-1}=0$ and $\pi_{1}=1-\gamma^{-1}$, respectively. Laggard banks make zero profit, as leaders capture the market and earn a profit equal to its revenue (normalized to one due to the income in the budget constraint) minus the costs (equal to the inverse of the innovation parameter $\gamma$ ). The profit of neck-and-neck banks ranges from zero to onehalf of the profits of a technological leader. The inability to collude leads to zero profits, as banks are assumed to be in Bertrand competition with undifferentiated products and similar unit costs, $\pi_{0}=\varepsilon \pi_{1}, \varepsilon \in\left[0, \frac{1}{2}\right]$. Competition is parameterized by $\Delta=1-\varepsilon$ and equals the incremental profit of an innovating bank in a leveled market normalized by the profit of a leader.

Aghion et al. derive the research intensities and examine how they are affected by changes in competition. It is assumed that the discount rate is zero $(r=0)$. The research intensities of neck-and-neck banks and laggards are $n_{0}=\sqrt{h^{2}+2 \Delta \pi_{1}}-h$ and $n_{-1}=$ $\sqrt{h^{2}+n_{0}^{2}+2 \pi_{1}}-h-n_{0}$, respectively. ${ }^{18}$ Differentiating these research intensities with respect to the competition parameter $\Delta$ gives (see Aghion et al. 2005b, footnote 23, p. 722):

$$
\begin{gathered}
\frac{\partial n_{0}}{\partial \Delta}=\frac{\pi_{1}}{n_{0}+h}>0 . \\
\frac{\partial n_{-1}}{\partial \Delta}=\frac{\partial n_{0}}{\partial \Delta}\left[-1+\frac{n_{0}}{n_{-1}+h+n_{0}}\right]<0 .
\end{gathered}
$$

\footnotetext{
${ }^{15}$ It is impossible for laggard banks to surpass a technological leader by means of an innovation without drawing even with this leader. See Aghion et al. (1997) for several appealing features of a model of step-bystep innovation compared to the Schumpeterian leapfrogging models.

${ }^{16}$ For example, it is possible to give a competitor a higher market share in one market to induce collusive behavior, while using the other market for disciplining purposes.

${ }^{17}$ Suppose that banks A and B are competitors in two local markets. If bank A is a technological leader in one market, this bank can use its technological advantage in both markets. This assumption implies that markets are either leveled or unleveled.

${ }^{18}$ See Aghion et al. (2005b) for a derivation of equilibrium research intensities as well as escape competition and Schumpeterian effects.
} 
Obviously, from the first order condition in equation (1), the research intensity of a neck-and-neck firm is positively affected by increases in the degree of competition (i.e., an escape-competition effect). Their innovation incentives increase with more competition, as their pre-innovation rents are reduced more than post-innovation rents. The first order condition in equation (2) shows that the research intensity of a laggard bank decreases as competition increases (i.e., a Schumpeterian effect). The reason for this negative effect on innovation is that more competition reduces the rents that a laggard bank can attain by innovating. Whether the escape competition or Schumpeterian effect dominates depends on the fraction of leveled and unleveled sectors in the steady state, as determined by the research intensities of laggards and neck-and-neck banks.

We diverge from Aghion et al. by examining how the average flow of innovations of a firm (as opposed to industry) changes with competition. The steady-state probabilities that a market is leveled and unleveled are $\mu_{0}$ and $\mu_{1}$, respectively. During any unit time interval, the steady-state probability that a market changes state (from leveled to unleveled or vice versa) is an aggregate of the probability of being a certain type of market times the Poisson hazard rate that firms move ahead. For unleveled and leveled markets this probability is $\mu_{1}\left(n_{-1}+h\right)$ and $2 \mu_{0} n_{0}$, respectively. The condition $\mu_{1}\left(n_{-1}+h\right)=2 \mu_{0} n_{0}$ must hold in the steady-state, as the fraction of leveled and unleveled markets must remain unchanged. The average flow of innovations for a firm in an intermediate sector is: ${ }^{19}$

$$
I=\mu_{0} n_{0}+\mu_{1}\left(n_{-1}+h\right)=1.5 \mu_{1}\left(n_{-1}+h\right)=\frac{3 n_{0}\left(n_{-1}+h\right)}{2 n_{0}+n_{-1}+h} .
$$

According to this equation, innovations for a firm in a certain (geographical) market follows an inverted-U pattern. ${ }^{20}$ The intuition is straightforward. If the degree of competition is initially low, neck-and-neck banks earn high profits and have little incentive to innovate. By contrast, laggard banks have relatively more incentive to innovate due to low initial profits (i.e., zero in the model) but high potential profits if they manage to catch up with a technological leader. We can infer that banks will leave their status as a neck-and-neck (laggard) bank relatively slowly (rapidly). Consequently, a bank will be a neck-and-neck bank most of the time, such that the escape-competition effect dominates. If there is not much competition in a market, increased competition should lead to a higher average innovation rate. The reverse is true in the case of high initial competition. Now laggard banks do not have much incentive to innovate due to little gain after a successful innovation. However, neck-and-neck banks have relatively more incentive to innovate due to large incremental potential profit. These outcomes imply that banks will leave their status as a neck-and-neck (laggard) bank relatively rapidly (slowly). In this scenario a bank will be a laggard bank most of the time, such that the Schumpeterian effect dominates and the leader never innovates. Hence, if the degree of competition is initially high, increased competition should lead to a lower average innovation rate.

\footnotetext{
${ }^{19}$ Since two neck-and-neck firms are trying to gain a technological lead, the average flow of innovations in an intermediate sector is equal to $I=2 \mu_{0} n_{0}+\mu_{1}\left(n_{-1}+h\right)$.

${ }^{20}$ See Aghion et al. (2005b) for the proof at the industry level.
} 


\section{Data and Methodology}

\subsection{Data}

Our dataset contains individual bank data over the period 1984-2004. Data are gathered from the Call Reports of Income and Condition provided by the Federal Reserve System. The Call Reports include complete balance sheet and income statement data for each bank. All data are expressed in 1984 U.S. dollars.

Table 1

Descriptive statistics

\begin{tabular}{lrrrrr}
\hline Variable & Observations & Mean & Std. Dev. & Minimum & Maximum \\
\hline Price cost margin & 151,476 & 0.179 & 0.090 & -0.993 & 0.964 \\
Total assets per in millions of USD & 151,476 & 458.740 & 7416.978 & 1.067 & 967,365 \\
Risk (Equity/Total Assets) & 151,476 & 0.096 & 0.034 & $7.36 \mathrm{e}-05$ & 0.998 \\
Salary expenses per fte in thousands of USD & 151,476 & 35.143 & 12.756 & 0.048 & 537.160 \\
\hline
\end{tabular}

The descriptive statistics are based on the sample of the preferred specification in Table 3 (specification 2).

Table 1 shows the descriptive statistics for the price cost margin, total assets, equity ratio, and average wage per fte-employee. The number of banks per year ranges from about 7,500 to around 14,000.

\subsection{Estimating technology gaps}

To examine the relationship between competition and innovation at the firm-level, we need a firm-specific measure of innovation that is appropriate for the banking industry. In order to distinguish the most innovative firms from the least innovative firms, the measure should be ordinal. Traditional innovation measures, such as patents or R\&D expenditures, are not obvious measures for service sectors such as banking (Frame and White, 2004). Moreover, these traditional measures have limitations (Kamien and Schwartz, 1982; Acs and Audretsch, 1987; Geroski, 1990; Griliches, 1990). For example, not all innovations are patented and R\&D expenditures may systematically understate the research activity of small firms.

For these reasons we propose to use changes in the estimated technology gap of firms as a measure of innovation. Specifically, changes in the technology gap represent relative improvements in technology sets, which in turn are affected by innovations. In his work on technology gap theory, Posner (1961) introduced the idea that temporary monopoly profits can be appropriated, based on a technological lead, in an international trade context. Given the assumption that technology is not a free and universally available good, Posner argued that, even though technology might be important for trade in some sectors and not in others, innovations made in one country (in technology intensive sectors) would benefit that country as long as the lead could be maintained. That is, a country will have ample first-mover advantages in a particular sector until 
other countries have imitated the innovation. Krugman (1986) extends the concept of technology gaps to international trade and trade-induced learning. ${ }^{21}$

Studies by Battese and Rao (2002), Battese, Rao, and O'Donnell (2004) and O'Donnell, Rao, and Battese (2008) use stochastic frontiers to estimate technology gaps. Particularly relevant to the present paper, Bos and Schmiedel (2007) estimate technology gap ratios for commercial banks. They test whether banks in European Union (E.U.) countries share a common minimum cost (and maximum profit) frontier. To do so they compare country-specific cost frontiers to an E.U.-wide meta frontier. The meta frontier is estimated as the envelope around country-specific frontiers and, therefore, represents the potential available technology. The relative distance between this meta frontier and the country-specific frontiers is the technology gap ratio.

Figure 1. Technology gap ratio

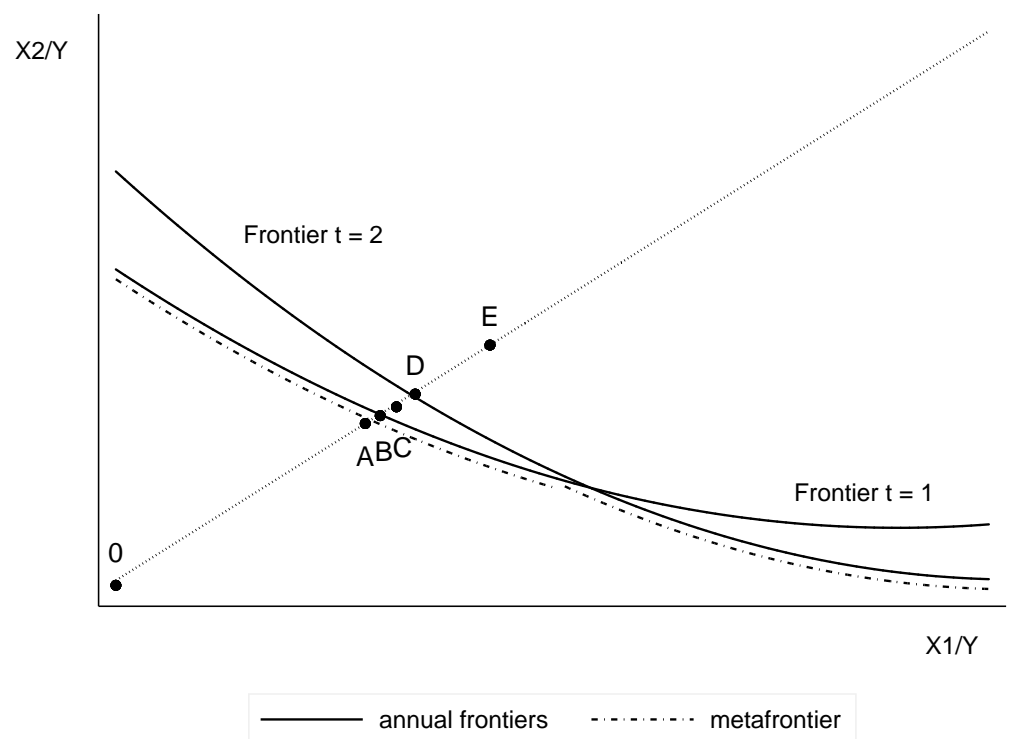

Figure 1 illustrates the rationale for our technology gap ratio with a simple example based on cost minimization with two inputs $\left(X_{1}, X_{2}\right)$ and a single output $(Y)$. In this example there are two annual frontiers at time $t=1$ and time $t=2$. Each frontier represents the minimum cost curve for a certain level of output for that year. That is, it captures the appropriate minimum cost frontier at a specific time $t .^{22}$ The dashed line in Figure 1 represents the minimum cost frontier over the whole period, or meta frontier. Innovation results in a lower gap between the annual minimum cost frontier and the meta frontier, where the latter is an envelope function of stochastic frontiers in

\footnotetext{
${ }^{21}$ See also related studies by Dosi et al. (1994), Grossman and Helpman (1994), Targetti and Foti (1997), Fagerberg and Verspagen (2002), and Acemoglu et al. (2007).

22 We borrow the concept of appropriate technology from Basu and Weil (1998).
} 
each time period. The technology gap ratio measures the difference between currently available technology and potentially available technology over the whole period with values between zero and one (i.e., the firm is on the meta frontier). The cost efficiency of a firm located at point $E$ at time $t=1$ is $O D / O E$. If the firm is at point $C$ at $t=2$, its efficiency is $O B / O C$. At $t=1$ the firm faces a technology gap of $O A / O D$, which narrows to $O A / O B$ at $t=2$ as the firm improves its technology set.

In this paper we follow Bos and Schmiedel (2007) and estimate annual cost frontiers for U.S. banks. We then estimate the envelope around these annual frontiers. We employ stochastic frontier analysis (SFA) to estimate translog cost frontiers. ${ }^{23}$ Banks are assumed to minimize total costs $\left(T C_{i t}\right)$, operate in perfectly competitive input markets, and produce inputs and outputs in line with the so-called "intermediation approach." We therefore define an output vector $Y$ consisting of three outputs: loans, investments, and off-balance sheet items. Output quantities are year-end stocks. Banks choose input quantities given factor costs. We define an input price vector $W$ consisting of three input prices: the price of fixed assets, price of labor, and price of borrowed funds. We calculate input prices as factor payments divided by input quantities. The price of fixed assets equals depreciation over fixed assets, the price of labor equals personnel expenses over the number of fte-employees, and the price of borrowed funds equals interest expenses over total borrowed funds. Following Hughes and Mester (1993), we include an equity to total assets ratio $Z$ to account for different risk profiles of banks.

For each year $t$, we can write the cost frontier as: ${ }^{24}$

$$
T C_{i t}=f^{*}\left(w_{i t}, y_{i t}, z_{i t}\right) e^{v_{i t}+u_{i t}},
$$

where the random noise component $v$ is i.i.d. $N\left(0, \sigma_{v}\right)$, and the inefficiency $u$ is i.i.d. $N\left|\left(\mu, \sigma_{u}\right)\right|$. Since cost inefficient banks operate above the efficient frontier, the latter term is added to random deviations, which results in a composed error of the form $\varepsilon_{i t}=$ $v_{i t}+u_{i t}$. Firm-specific estimates of the inefficiency term are obtained from the expected value of $u_{i t}$ conditional on total error $\epsilon_{i t}$ (i.e., $E\left(u_{i t} \mid \epsilon_{i t}\right)$ ). Subsequently, estimates of cost efficiency are obtained from:

$$
C \hat{E}_{i t}=\left[\exp \left(-\hat{u}_{i t}\right)\right]
$$

where efficient banks operate on the minimum cost frontier $\left(C \hat{E}_{i t}=1\right)$, and inefficient banks operate above the frontier. Estimating equation (4) for each year $t$ provides annual minimum cost frontiers. For the period 1984-2004, 21 annual frontiers are estimated. We seek to measure movements of this frontier over time without the confounding influence of efficiency changes (i.e., movements towards this frontier). ${ }^{25}$ We therefore use

\footnotetext{
${ }^{23}$ Kumbhakar and Lovell (2000) provide an excellent discussion of the development and application of SFA to efficiency measurement.

${ }^{24}$ We use a translog functional form and impose homogeneity of degree one in input prices and symmetry.

${ }^{25}$ Conventional studies have applied stochastic frontiers to measure technical change by including a time trend variable and interaction terms in the translog specification (Altunbas et al., 1999). As noted by Baltagi and Griffin (1988), one of the problems with this approach is that pure technical change is assumed to be linearly increasing or decreasing over time. In this respect, Baltagi and Griffin (1988) recommend the use of time dummies interacted with the other variables in the translog specification. Although this approach results in a general index of technical change that is indeed more flexible, possible correlation between efficiency and technical change may still affect the latter.
} 
parameter estimates for the annual cost frontier and produce estimates of the technology gap (GAP) by estimating the minimum cost meta frontier $\left(f_{\text {meta }}\right)$ :

$$
\text { Min.GAP }=\sum_{t=1}^{T} \sum_{i=1}^{N}\left|\ln f^{*}\left(w_{i t}, y_{i t}, z_{i t}\right)-\ln f_{\text {meta }}\left(w_{i t}, y_{i t}, z_{i t}\right)\right|, \text { s.t. } \ln f_{\text {meta }}(\cdot) \leq \ln f^{*}(\cdot) \text {. }
$$

Equation (6) minimizes the distance between the meta frontier and the annual frontiers, with the constraint that the latter are not below the former. ${ }^{26}$ Now we can measure the total distance of a firm from the meta frontier or "meta efficiency" as follows:

$$
M E_{i t}=\frac{f_{\text {meta }}\left(w_{i t}, y_{i t}, z_{i t}\right) e^{v_{i t}}}{T C_{i t}}=\frac{f^{*}\left(w_{i t}, y_{i t}, z_{i t}\right) e^{v_{i t}}}{T C_{i t}} \cdot \frac{f_{\text {meta }}\left(w_{i t}, y_{i t}, z_{i t}\right)}{f^{*}\left(w_{i t}, y_{i t}, z_{i t}\right)}=C E_{i t} \cdot T G R_{i t},
$$

where $T G R_{i t}$ is the firm's technology gap ratio consistent with the simple example in Figure 1. We use this measure to gauge each firm's technology gap. Table 2 shows the descriptive statistics for the estimated technology gap ratios.

Table 2

Technology gap ratios

\begin{tabular}{lrrrrr}
\hline Variable & Observations & Mean & Std. Dev. & Minimum & Maximum \\
\hline Technology gap ratio & 151,476 & 0.989 & 0.029 & $1.07 \mathrm{e}-08$ & 1.000 \\
\hline
\end{tabular}

The descriptive statistics are based on the sample of the preferred specification in Table 3 (specification 2).

We can now relate the role innovation plays in the model of Aghion et al. to the technology gap ratio derived in equation (7) and depicted in Figure 1. Recall that some of the crucial assumptions of their model include the fact that leaders do not innovate, and that the maximum gap remains one. In addition, innovations are expected to lower the unit cost of production, and laggards cannot surpass the leader without first drawing even. Clearly, the technology gap ratio we have derived here is in line with each of these assumptions. A leader will be on the (annual) cost frontier, even if that shifts, as in Figure 1. Throughout, his TGR will remain 1. Likewise, a laggard can close the technology gap, by lowering his cost, and moving towards the cost frontier. Summing up, the technology gap ratio as a measure of innovation is closely aligned with the concept of innovation as described by Aghion et al..

\subsection{Measuring competition}

We follow Aghion et al. (2005b) by using the price cost margin (viz., Lerner index, or markup) as the main indicator of competition and subtract it from one as follows:

$$
C_{i t}=1-\left(\frac{\Pi_{i t}+F_{i t}}{R_{i t}}\right),
$$

\footnotetext{
${ }^{26}$ Details concerning our estimation procedure are available on request from the authors.
} 
where $\Pi_{i t}$ is the profit of a bank, $F_{i t}$ represents fixed costs, and $R_{i t}$ denotes sales. The price cost margin is calculated by dividing the net income after taxes and extraordinary items plus expenses of premises and fixed assets by total non-interest income plus total interest income. The competition measure ranges between zero and two after removal of outliers. ${ }^{27}$

\subsection{Empirical specifications and estimation procedures}

We present several empirical specifications based on the following general model:

$$
T G R_{i t}=\beta_{1} C_{i t}+\beta_{2} C_{i t}^{2}+\gamma^{\prime} \mathbf{Z}_{i t}+a_{i}+\varepsilon_{i t},
$$

where the technology gap ratio is the dependent variable, $C_{i t}$ is the competition variable, $\gamma^{\prime}$ is a $1 \times n$ parameter vector, and $\mathbf{Z}_{i t}$ is a $n \times 1$ vector of control variables. A squared term for the competition variable is included to account for the inverted-U relationship between competition and innovation proposed by Aghion et al.. Taking the firstdifferences of equation (9) to eliminate the unobserved heterogeneity $a_{i}$ gives:

$$
\Delta T G R_{i t}=\beta_{1} \Delta C_{i t}+\beta_{2} \Delta C_{i t}^{2}+\gamma^{\prime} \Delta \mathbf{Z}_{i t}+\Delta \varepsilon_{i t} .
$$

A common problem in competition-innovation studies is the difficulty associated with finding suitable instruments for the competition variable. The competition variable is endogenous due to reverse causality with the innovation variable. Even though many papers do not control for the endogeneity of competition, they interpret the results as a causal effect of competition on innovation. The danger in interpreting the results in this way is that innovation may also have an effect on competition (e.g., if innovation reduces competition) and hence leads to biased coefficient estimates. For this reason it is impossible to draw conclusions about causal relationships without using exogenous instruments. To deal with the endogenous competition variable, it is necessary to find relevant instruments (i.e., correlated with the endogenous variable) that are not correlated with the error term (instrument exogeneity). We use the two-step efficient generalized method of moments estimator (GMM), where lags of these endogenous variables in levels are used as instruments for the endogenous variables in first-differences. ${ }^{28}$ The lag structure will depend on the order of serial correlation in the residuals. If there is no serial correlation in the residuals (in levels), lags from period $t-2$ (onwards) can be used as instruments. However, if there is first-order serial correlation (in the residual in lev-

\footnotetext{
$\overline{27}$ Outliers were removed after visual inspection of scatter plots of the technology gap ratio against the price cost margin. A range between -1 and 1 for the price cost margin was considered to be reasonable. Therefore, the analysis excludes 1,324 observations (i.e., less than $1 \%$ of the total amount of observations). Some authors choose to remove negative price cost margins, but this approach creates a bias in the results as only firms with positive profits are considered. Our empirical findings were robust to different thresholds.

28 The OLS estimations are only performed for exploratory purposes, as the OLS estimator gives biased and inconsistent estimates of causal effects in the presence of endogenous regressors. GMM has some efficiency gains compared to the traditional IV /2SLS estimator. For example, the efficient GMM estimator utilizes an optimal weighting matrix that minimizes the asymptotic variance of the estimator. Also, GMM is more efficient than the 2SLS estimator in the presence of heteroskedasticity.
} 
els), lags from period t-3 must be used. An important assumption is that these lags are not correlated with the disturbance term. ${ }^{29}$

Additionally, we employ a model specification in which interstate banking deregulation at the state level is used as an instrument. Before the late 1970s, restrictions on interstate banking protected banks from outside competition. Deregulation concerning interstate banking unleashed competitive forces by allowing banks to enter new markets and pose a threat to incumbent banks (Stiroh and Strahan, 2003). This regime shift is a dummy variable that takes the value 1 from the year in which states entered into an interstate banking agreement with other states, and 0 before this year. ${ }^{30}$ However, it is questionable whether such policy reforms in the banking sector are suitable instruments for competition. Kroszner and Strahan (1999) argue that several technological and financial innovations influenced the deregulation process by affecting the lobby behavior of banks. In this regard, these authors cite some specific technologies (e.g., the introduction of the ATM) that spurred banks' efforts to seek deregulation. Even though the technology gap ratio captures a broad spectrum of implemented innovations, the endogeneity of this regime shift due to its concomitant reverse causality with technological developments remains questionable.

One empirical drawback of neglecting control variables in equation (9) is that other factors that are correlated with competition can influence innovation. Therefore, we introduce a model specification with several control variables, which allows for the possibility that the elements of the parameter vector $\gamma^{\prime}$ are nonzero. Our control variables are as follows: equity divided by total assets, firm size in terms of total assets, and the average wage per fte-employee. Equity to total assets is an inverse measure of debt pressure. Aghion et al. (2005a) argue that debt pressure is positively related to innovation, as firms increase innovation to escape the threat of bankruptcy. The relationship between firm size and innovation is a Schumpeterian hypothesis. Plausible explanations of a positive relationship between firm size and innovation are potential scale economies in R\&D and diversification benefits that lower risk (Kamien and Schwartz, 1982). Lastly, the variable average wage per full-time equivalent employee proxies for labor productivity and, therefore, is positively related to innovation.

We also estimate equation (10) for two different time periods to examine the stability of the inverted-U pattern over time. The Riegle-Neal Interstate Banking and Branching Efficiency Act of 1994 eliminated the interstate banking restrictions at the national level and is used to demarcate two periods: 1984-1993 and 1994-2004.

\section{Results}

This section describes the empirical results. First, we test for the inverted-U relationship. Second, we examine the robustness of our results by comparing them to alternative

\footnotetext{
${ }^{29}$ An argument against the exogeneity of these lags is that the dependent variable in the current period may reflect expectations in the past. If behavior in the past is based on expectations of the future, these lags as instruments are not exogenous. For example, the technology gap ratio in the current period may reflect expectations concerning the technology gap in previous periods, and this expectation may have affected competitive behavior in the past.

${ }^{30}$ See Stiroh and Strahan (2003) for an overview of the deregulation year for each state.
} 
specifications. ${ }^{31}$ Third, we investigate how the interstate banking deregulation process, which was aimed in part at enhancing competition, affected innovation. Fourth, and last, we evaluate the effect of the consolidation process on innovation in U.S. banking.

\subsection{Is there an inverted-U relationship?}

Our main focus is to examine the effect of competition on innovation in U.S. banking. Table 3 shows the results of the basic specification and the preferred specification.

Table 3

Competition and technology gaps

\begin{tabular}{|c|c|c|}
\hline Based on equation (10) & Specification (1) & Specification (2) \\
\hline Estimation procedure & OLS & Two-step GMM \\
\hline \multirow[t]{2}{*}{$\Delta$ Competition $_{i t}$} & $0.0600^{* * *}$ & $1.600^{* * *}$ \\
\hline & $(0.009)$ & $(0.095)$ \\
\hline \multirow[t]{2}{*}{$\Delta$ Competition $_{i t}^{2}$} & $-0.038^{* * *}$ & $-0.844^{* * *}$ \\
\hline & $(0.005)$ & $(0.058)$ \\
\hline $\mathrm{AR}(1)$ & 0.000 & 0.000 \\
\hline $\operatorname{AR}(2)$ & 0.000 & 0.000 \\
\hline $\operatorname{AR}(3)$ & 0.100 & 0.969 \\
\hline Optimal price cost margin & $21.800 \%$ & $5.200 \%$ \\
\hline \multirow[t]{2}{*}{ Sargan-Hansen J statistic } & & 1.064 \\
\hline & & $(0.588)$ \\
\hline Observations & 198,785 & 151,476 \\
\hline
\end{tabular}

Standard errors (between parentheses) are robust against heteroskedasticity and serial correlation with significance at the following levels: ${ }^{*}-0.10,{ }^{* *}$ 0.05 , and ${ }^{* * *}-0.01$. The $p$-values are reported for the Arellano-Bond serial correlation test. The chi-squared statistic and the p-value are reported for the endogeneity test and the Hansen test. The endogeneity test (difference-inSargan) is performed on the competition variables.

We find a statistically significant (individually and jointly) inverted-U relationship between competition and the technology gap ratio in both model specifications. ${ }^{32}$ The basic model specification shows the estimation results without dealing with the endogeneity of the competition variable. The optimal price cost margin is around $21.8 \%$. However, the OLS estimator yields biased and inconsistent estimates of the causal effect of the regressor on an outcome in the presence of endogenous regressors. The competition variable and its squared term are endogenous from a theoretical point of view

\footnotetext{
${ }^{31}$ We also performed a Kernel regression to allow for more flexibility in the relationship between competition and the technology gap ratio. The Kernel regression also shows evidence of an inverted-U relationship between competition and innovation.

${ }^{32}$ The $\mathrm{p}$-value of the F-test is zero in both specifications.
} 
due to reverse causality with innovation. ${ }^{33}$ The second model specification shows the results with lagged values in levels of the competition variable and its squared term. ${ }^{34}$ Since the Arellano-Bond test for serial correlation indicates first-order autocorrelation in the residuals in levels, the lags are taken from periods $\mathrm{t}-3$ and $\mathrm{t}-4 .{ }^{35}$ As such, lags from period $\mathrm{t}-2$ cannot be used. According to the Sargan-Hansen test, the joint null hypothesis that the instruments are valid cannot be rejected. ${ }^{36}$ The optimal price cost margin in specification (2) is around $5.2 \% .{ }^{37}$

Based on the second (preferred) model specification, Figure 2 shows the empirical relationship between the technology gap ratio and competition measure. These findings are consistent with the theoretical and empirical results of Aghion et al. (2005b) and empirical work of Hashmi (2007). Aghion et al. use U.K. data (industry-averages) over the period 1973-1994 and find an optimal price cost margin around 6.0\% after using policy instruments to deal with the endogeneity of competition (see Aghion et al. 2005b, Table 1, specification 4, p. 708). Hashmi (2007) also conducts an industry-level analysis based on data from publicly-traded manufacturing firms in the U.S. over the period 1970-1994. Instead of using an instrumental variable approach, he uses the first lag of the competition variable and the squared term directly. His empirical results indicate an optimal price cost margin around 22.9\% (see Hashmi (2007), Table 2 (first specification), p.13).

To examine the robustness of our results, we check whether an inverse- $U$ relationship exists for a number of alternative model specifications. Table 4 gives the results. As shown there, model specification (3) includes several control variables, and lagged values of the competition variable (from periods $t-3$ and $t-4$ ) are used as instruments. An inverted-U relationship between competition and technology gap ratio is again ob-

\footnotetext{
${ }^{33}$ We also performed the Hausman-Wu endogeneity test based on specification (2) to examine the endogeneity of the competition variable and its squared term. The endogeneity test showed that the competition variable should be treated as an endogenous regressor (i.e., the p-value of the F-test was zero).

${ }^{34}$ An important drawback of the two-step efficient GMM estimator is that the standard errors are downward biased in small samples. Windmeijer (2005) proposes a finite sample corrected estimate of the variance. The corrected variance leads to more accurate inference in small samples. There is also a finite sample bias of the GMM estimator itself. Therefore, the correction of the variance is only useful for improving inference when the GMM estimator does not contain a large finite sample bias. However, these issues may not be a problem with the dataset used in this paper, as there is on average about 11,000 banks in the sample over a period of 21 years. As a robustness check, we performed regressions with the Windmeijer correction. As expected, the correction had a negligible effect on the standard errors.

35 This serial correlation test is based on the examination of residuals in first differences. Testing for first-order serial correlation in levels is based on testing for second-order serial correlation in first differences.

${ }^{36}$ We performed an instrument relevance test based on the joint significance of the instruments. The Fstatistics for the regressions with the competition variable and its squared term as a dependent variable are 905.16 and 545.13, respectively. Since an F-statistic of 10 is often used as a rule of thumb to examine instrument relevance, we conclude that the instruments are relevant.

${ }^{37}$ Translated into 1984 dollars, a one percentage point decrease in the price cost margin results on average in approximately $\$ 627,000,000$ (1984 dollars) lower costs for the whole banking sector (evaluated at the average number of banks per year in the sample of about 11,000). This number is obtained by evaluating the marginal effect of the competition variable on the technology gap ratio at the average price cost margin. The marginal effect on the technology gap ratio is translated into annual frontier dollar values evaluated at the average metafrontier, average technology gap ratio, and the average technology gap ratio plus the marginal effect.
} 
Figure 2. The estimated relationship between the technology gap ratio and competition

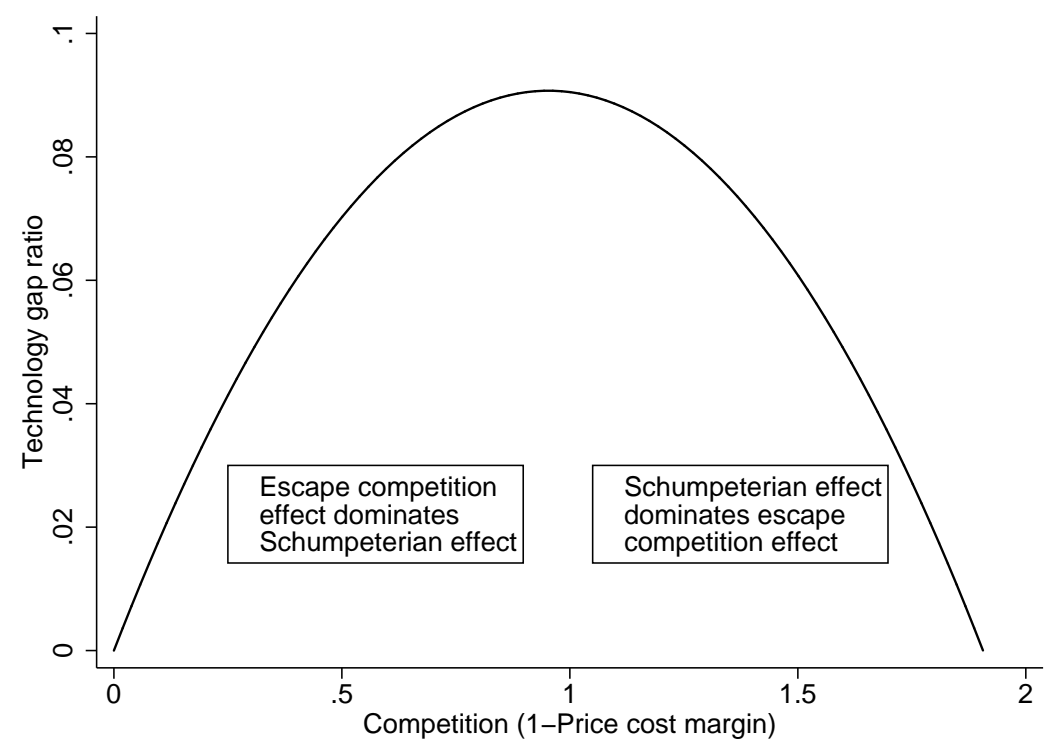

tained after controlling for other factors that may affect this ratio. According to the Sargan-Hansen test, the instruments are valid in this specification. The optimal price cost margin is around $5.8 \%$ and thus higher than the optimal markup from the second specification. The risk variable (equity divided by total assets) is significant at the $1 \%$ level. A decrease in the equity ratio is positively related to the technology gap ratio. This finding is consistent with the theory of Aghion et al. (2005a) that more debt pressure may lead to more innovation. Both firm size and the average wage per fte-employee are not significantly related to the technology gap ratio.

In model specification (4) the lag structure of the instruments is changed by using lags of the competition variable and its squared term from period $t-3$. A regime shift associated with interstate banking deregulation in 1994 is added to the instrument set, such that there is one over-identifying restriction. The instruments are valid based on the Sargan-Hansen test. According to the Arellano-Bond serial correlation test, there is no evidence of first order serial correlation in the residuals in levels. Hence, it would be appropriate to use the lag from period $t-2$ as an instrument also. We have chosen lags from period $t-3$, as many specifications showed some evidence of first-order serial correlation and therefore contradicted the result from this test in specification (4). We find a statistically significant (individually and jointly) inverted-U relationship between competition and the technology gap ratio, with an optimal markup of approximately $5.4 \%$. Model specifications (5) and (6) show the results for time periods before and after the Riegle-Neal Interstate Banking and Branching Efficiency Act of 1994, respectively. Again, the inverted-U pattern is robust in these two time periods. 
Table 4

Competition and technology gaps: alternative specifications

\begin{tabular}{|c|c|c|c|c|}
\hline Based on equation (10) & Specification (3) & Specification (4) & Specification (5) & Specification (6) \\
\hline Estimation procedure & Two-step GMM & Two-step GMM & Two-step GMM & Two-step GMM \\
\hline Period & 1984-2004 & 1984-2004 & 1984-1993 & 1994-2004 \\
\hline \multirow[t]{2}{*}{$\Delta$ Competition $_{i t}$} & $1.474^{* * *}$ & $1.424^{* * *}$ & $0.678^{* * *}$ & $2.511^{* * *}$ \\
\hline & $(0.106)$ & $(0.069)$ & $(0.070)$ & $(0.180)$ \\
\hline \multirow[t]{2}{*}{$\Delta$ Competition $_{i t}^{2}$} & $-0.783^{* * *}$ & $-0.753^{* * *}$ & $-0.336^{* * *}$ & $-1.369^{* * *}$ \\
\hline & $(0.062)$ & $(0.042)$ & $(0.041)$ & $(0.121)$ \\
\hline \multirow[t]{2}{*}{$\Delta$ Equity $_{i t} /$ total $_{\text {assets }}$ it } & $-0.124^{* * *}$ & & & \\
\hline & $(0.037)$ & & & \\
\hline \multirow[t]{2}{*}{$\Delta$ Total assets $i t(\$ 1,000,000)$} & $-8.51 \mathrm{e}-08$ & & & \\
\hline & $(6.40 \mathrm{e}-08)$ & & & \\
\hline \multirow[t]{2}{*}{$\Delta$ Average wage per fte ${ }_{i t}$} & $-5.88 e-05$ & & & \\
\hline & $(5.74 \mathrm{e}-05)$ & & & \\
\hline $\mathrm{AR}(1)$ & 0.000 & 0.000 & 0.000 & 0.000 \\
\hline $\mathrm{AR}(2)$ & 0.000 & 0.000 & 0.002 & 0.000 \\
\hline $\mathrm{AR}(3)$ & 0.795 & 0.814 & 0.798 & 0.899 \\
\hline Optimal price cost margin & $5.800 \%$ & $5.400 \%$ & $-0.007 \%$ & $8.300 \%$ \\
\hline \multirow[t]{2}{*}{ Hansen J statistic } & 0.797 & 2.089 & 1.151 & 1.071 \\
\hline & $(0.671)$ & $(0.148)$ & $(0.562)$ & $(0.585)$ \\
\hline Observations & 151,476 & 166,437 & 65,020 & 86,456 \\
\hline
\end{tabular}

Standard errors (between parentheses) are robust against heteroskedasticity and serial correlation with significance at the following levels: ${ }^{*}-0.10,{ }^{* *}-0.05$, and ${ }^{* * *}-0.01$. The p-values are reported for the Arellano-Bond serial correlation test. The chi-squared statistic and p-value are reported for the endogeneity test and Hansen test. The endogeneity test is performed on the firm size and competition variables.

\subsection{How has the interstate banking deregulation affected competition in U.S. banking?}

In model specification (4) interstate banking deregulation in 1994 was used as an instrument for competition. ${ }^{38}$ This dummy variable assumes that the effect of deregulation was absorbed immediately in the competitive environment. However, if the dynamics are more complex, this assumption can lead to model misspecification. To allow for flexibility in the response function, we construct a dummy variable for every two consecutive years after the deregulation year. The response function is estimated by regressing the competition variable on the full set of dummy variables that captures the dynamic effects of deregulation: ${ }^{39}$

\footnotetext{
${ }^{38}$ We also estimated a specification in which we regressed the technology gap ratio on the competition variables and the deregulation variable as a control variable. The deregulation variable was insignificant in this specification.

${ }^{39}$ The equation is estimated in first-differences to eliminate constant unobserved heterogeneity over time.
} 


$$
C_{i t}=\sum_{k=1}^{7} \alpha_{k} D_{k s t}+a_{i}+\varepsilon_{i t},
$$

where $C_{i t}$ is the competition variable, and $D_{k s t}$ is the deregulation variable that has been in effect for period $k$ in state $s$. Each period consists of two consecutive years starting from year 1 until year 13. Only the last period consists of more than two years and captures the effect of the deregulation from year 13 and thereafter in the postimplementation period. Table 5 shows the results.

Table 5

Competition and the dynamic effect of interstate banking deregulation

\begin{tabular}{ll}
\hline Based on equation (11) & \\
Estimation procedure & OLS \\
\hline$\Delta$ Years $1-2$ & -0.000 \\
& $(0.001)$ \\
$\Delta$ Years $3-4$ & $-0.003^{* *}$ \\
& $(0.001)$ \\
$\Delta$ Years $5-6$ & $-0.007^{* * *}$ \\
& $(0.002)$ \\
$\Delta$ Years $7-8$ & $-0.024^{* * *}$ \\
& $(0.002)$ \\
$\Delta$ Years $9-10$ & $-0.026^{* * *}$ \\
& $(0.002)$ \\
$\Delta$ Years $11-12$ & $-0.029^{* * *}$ \\
$\Delta$ Years $13-$ thereafter & $(0.002)$ \\
& $-0.037^{* * *}$ \\
\hline Observations & $(0.002)$ \\
\hline
\end{tabular}

Standard errors (between parentheses) are robust against heteroskedasticity and serial correlation with the following significance levels: ${ }^{*}-0.10,{ }^{* *}-0.05$, and ${ }^{* *}-0.01$.

Most regression coefficients are negative and suggest that deregulation of interstate banking had an adverse effect on competition. ${ }^{40}$ We performed an F-test to investigate whether the responses are homogenous over time. The null hypothesis that the slope coefficients are equal to each other is rejected at the $1 \%$ level. ${ }^{41}$ A possible explanation for the decrease in competition is that more multi-market contact (due to the interstate banking deregulation) facilitated tacit collusion. These results are also consistent with

\footnotetext{
$\overline{40}$ There seems to be no significant effect in the first two years after deregulation.

41 The p-value of the F-test is zero.
} 
the findings of Stiroh and Strahan (2003), who argue that the banking deregulations triggered a reallocation of banking assets from low profit to high profit banks and resulted in increased profitability in the banking sector. Hence, the reallocation process in the industry led to higher price cost margins on average. Figure 3 shows a clear downward trend in the response of competition to interstate banking deregulation.

Figure 3. The response of competition to interstate banking deregulation

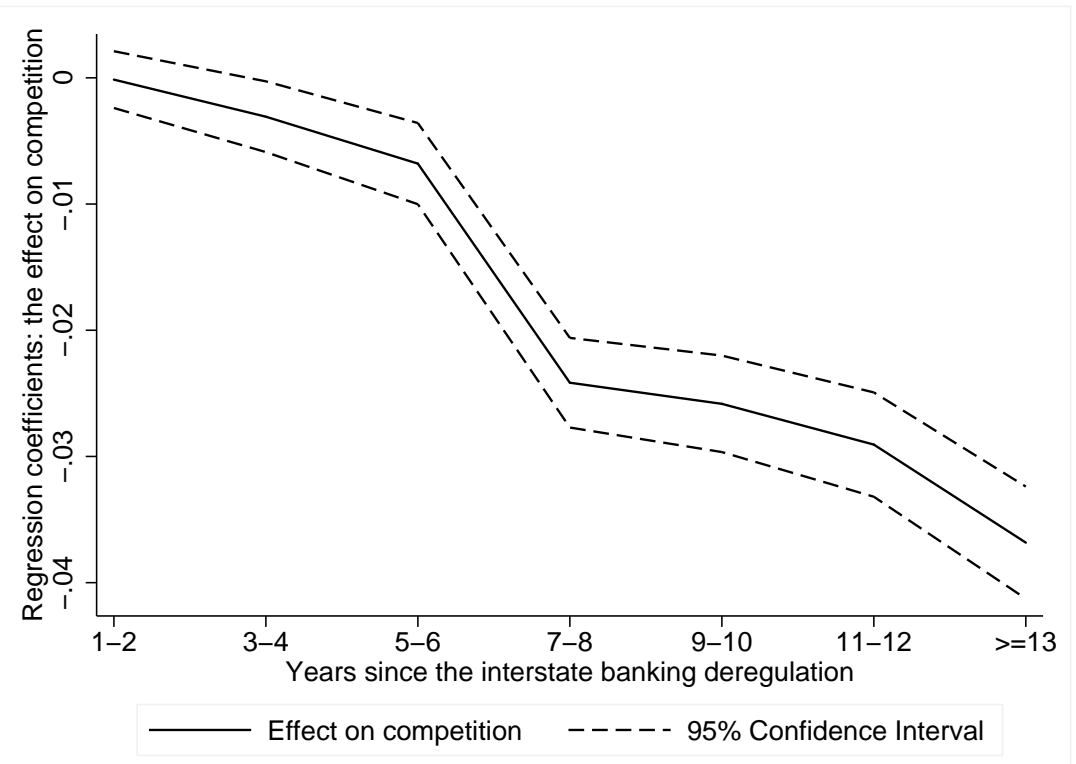

This evidence suggests that the negative competitive effects of the regime shift increased over time. Hence, interstate banking deregulation triggered a leftward movement of competition in Figure 2. To make inferences about its effects on innovation, we need to know the level of competition before deregulation. The average price cost margin before the year of deregulation is $10.5 \%$. This is higher than the optimal price cost margin in all of the specifications, except for the first specification in which endogeneity problems are not treated. In view of the inverted-U relationship between competition and innovation, we infer that the technology gap ratio decreased on average after the deregulation of interstate banking (i.e., the leftward movement begins left of the optimal point).

\subsection{Has consolidation gone too far?}

During the consolidation process, the number of banks declined and average bank size increased. These trends have important implications for market structure and competition in the U.S. banking industry. Figure 4 shows the development of the average price cost margin and the number of banks over the sample period 1984-2004. 
Figure 4 . The average price cost margin and the number of banks

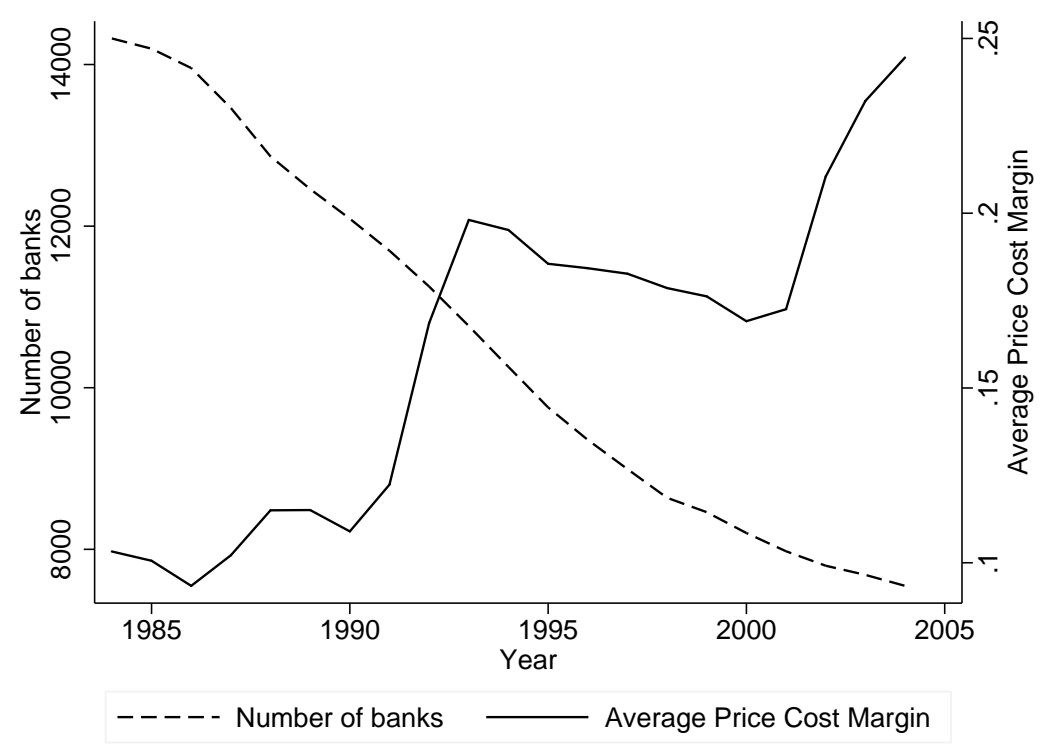

In this period the number of banks declined from 14,323 in 1984 to 7,548 in 2004 , while the average price cost margin increased from $9.3 \%$ in 1984 to $24.5 \%$ in 2004 . The average price cost margin in 1984 was already higher than the optimal markup in our preferred specification (or 5.2\%) and most of our other model specifications (except for the OLS results). However, the average price cost margin declined in some years in our sample period. For example, the average price cost margin declined every year from 1993 at $19.8 \%$ to 2000 at $16.9 \%$. This means that movements along the inverted-U relationship were toward the optimal point that enhances innovation. Nevertheless, the average price cost margins soared again in 2001 to 2004 from around $17.3 \%$ to approximately $24.5 \%$. This translates into a movement away from the optimal point, given that banks were positioned on average to the left side of the inverted-U relationship during the whole sample period. Thus, we find that: (1) the consolidation process was accompanied by a large increase in average price cost margins, and (2) U.S. banks are on average not operating at the optimal point that enhances innovation.

\section{Conclusion}

The U.S. banking industry experienced historic structural and competitive changes due to a consolidation wave over the past two decades. Contributing to the endogenous growth theory and industrial organization literature, the present paper seeks to examine the relationship between competition and innovation in U.S. banking. We also investigate the effects of interstate banking deregulation and major consolidation on bank competition and innovation. To do this we estimate technology gap ratios obtained 
from meta frontier analyses of U.S. banks in the sample period 1984-2004.

Consistent with Aghion et al. (2005b) and others, our empirical results suggest an inverted-U relationship between competition and innovation in the U.S. banking industry. This relationship is robust to alternative model specifications in which control variables and different instruments are used, in addition to different sample periods.

We also find that interstate banking deregulation negatively affected competition on average. The downward trend in competition after this deregulation implies a leftward movement along the inverted-U curve. Since banks were below (or left of) the optimal level of competition in our sample period, interstate banking deregulation tended to reduce innovation on average.

Importantly, our analyses show that the consolidation movement has been accompanied by marked increases in the price cost margins of banks over time (e.g., from $9.3 \%$ in 1984 to $24.5 \%$ in 2004). These margins are higher than the optimal price cost margins in most of our model specifications. Given ongoing consolidation due to mergers and acquisitions of troubled banks in the 2008-2009 financial and economic crises, as well as the average position of banks on the inverted-U curve, we infer that further diminution of competition could negatively affect the innovation incentives of banks in the future.

\section{References}

Acemoglu, D., Antrandagraves, P., Helpman, E., 2007. Contracts and technology adoption. American Economic Review 97 (3), 916-943.

Acs, Z. J., Audretsch, D. B., 1987. Innovation in large and small firms. Economics Letters $23(1), 109-112$.

Aghion, P., Bloom, B., Blundell, R., Griffith, R., Howitt, P., 2005a. Competition and innovation: An inverted-U relationship. NBER Working Paper 9269.

Aghion, P., Bloom, N., Blundell, R., Griffith, R., Howitt, P., 2005b. Competition and innovation: An inverted-U relationship. Quarterly Journal of Economics 120 (2), 701-728.

Aghion, P., Griffith, R., 2005. Competition and Growth: Reconciling Theory and Evidence. MIT Press, Cambridge, MA.

Aghion, P., Harris, C., Howitt, P., Vickers, J., 2001. Competition, imitation and growth with step-by-step innovation. Review of Economic Studies 68 (3), 467-492.

Aghion, P., Harris, C., Vickers, J., 1997. Competition and growth with step-by-step innovation: An example. European Economic Review 41 (3-5), 771-782.

Akhavein, J., Frame, W. S., White, L. J., 2005. The diffusion of financial innovations: An examination of the adoption of small business credit scoring by large banking organizations. The Journal of Business 78 (2), 577-596.

Allen, F., Gale, D., 1994. Financial Innovation and Risk Sharing. MIT Press, Cambridge, MA.

Altunbas, Y., Goddard, J., Molyneux, P., 1999. Technical change in banking. Economics Letters 64 (2), 215-221.

Baltagi, B. H., Griffin, J. M., 1988. A general index of technical change. Journal of Political Economy 96 (1), 20-41.

Basu, S., Weil, D. N., 1998. Appropriate technology and growth. The Quarterly Journal of Economics 113 (4), 1025-1054. 
Battese, G. E., Rao, D. S. P., 2002. Technology gap, efficiency and a stochastic metafrontier function. International Journal of Business and Economics 1 (2), 87-93.

Battese, G. E., Rao, D. S. P., O'Donnell, C. J., 2004. A metafrontier production function for estimation of technical efficiencies and technology gaps for firms operating under different technologies. Journal of Productivity Analysis 21 (1), 91-103.

Ben-Horim, M., Silber, W., 1977. Financial innovation : A linear programming approach. Journal of Banking and Finance 1 (3), 277-296.

Berger, A. N., Demsetz, R. S., Strahan, P. E., 1999. The consolidation of the financial services industry: Causes, consequences, and implications for the future. Journal of Banking and Finance 23 (2-4), 135-194.

Berger, A. N., Frame, W. S., Miller, N. H., 2005. Credit scoring and the availability, price and risk of small business credit. Journal of Money, Credit and Banking 37 (2), 191222.

Berger, A. N., Kashyap, A. K., Scalise, J. M., 1995. The transformation of the U.S. banking industry: What a long, strange trips it's been. Brookings Papers on Economic Activity 26 (1995-2), 55-218.

Berger, A. N., Mester, L. J., 1997. Efficiency and productivity change in the U.S. commercial banking industry: A comparison of the 1980s and 1990s. Federal Reserve Bank of Philadelphia Working Paper 97-5.

Berger, A. N., Mester, L. J., 2003. Explaining the dramatic changes in performance of US banks: Technological change, deregulation, and dynamic changes in competition. Journal of Financial Intermediation 12 (1), 57-95.

Bhattacharyya, S., Nanda, V., 2000. Client discretion, switching costs, and financial innovation. Review of Financial Studies 13 (4), 1101-1127.

Boot, A. W., Thakor, A. V., 1997. Banking scope and financial innovation. Review of Financial Studies 10 (4), 1099-1131.

Bos, J. W. B., Schmiedel, H., 2007. Is there a single frontier in a single European banking market? Journal of Banking and Finance 31 (7), 2081-2102.

Carletti, E., Hartmann, P., Spagnolo, G., 2007. Bank mergers, competition, and liquidity. Journal of Money, Credit and Banking 39 (5), 1067-1105.

Carow, K. A., 1999a. Evidence of early-mover advantages in underwriting spreads. Journal of Financial Services Research 15 (1), 37-55.

Carow, K. A., 1999b. Underwriting spreads and reputational capital: An analysis of new corporate securities. Journal of Financial Research 22 (1), 15-28.

Carow, K. A., Staten, M. E., 1999. Debit, credit, and cash: Survey evidence on gasoline purchases. Journal of Economics and Business 51 (5), 409-422.

Cetorelli, N., Strahan, P. E., 2006. Finance as a barrier to entry: Bank competition and industry structure in local U.S. markets. The Journal of Finance 61 (1), 437-461.

Chourchane, M., Nickerson, D., Sullivan, R. J., 2002. Financial innovation, strategic real options, and endogenous competition: Theory and an application to internet banking. Federal Reserve Bank of Philadelphia, Conference on Innovation in Financial Services and Payments.

Dosi, G., Fabiani, S., Aversi, R., Meacci, M., 1994. The dynamics of international differentiation: A multi-country evolutionary model. Industrial and Corporate Change 3 (1), 225-242.

Elyasiani, E., Mehdian, S. M., 1990. A nonparametric approach to measurement of efficiency and technological change: The case of large U.S. commercial banks. Journal of 
Financial Services Research 4 (2), 157-168.

Fagerberg, J., Verspagen, B., December 2002. Technology-gaps, innovation-diffusion and transformation: An evolutionary interpretation. Research Policy 31 (8-9), 1291-1304.

Frame, W. S., Srinivasan, A., Woosley, L., 2001. The effect of credit scoring on smallbusiness lending. Journal of Money, Credit and Banking 33 (3), 813-825.

Frame, W. S., White, L. J., 2004. Empirical studies of financial innovation: Lots of talk, little action? Journal of Economic Literature 42 (1), 116-144.

Furst, K., Lang, W. W., Nolle, D. E., 2002. Internet banking. Journal of Financial Services Research 22 (1-2), 95-117.

Geroski, P. A., 1990. Innovation, technological opportunity, and market structure. Oxford Economic Papers 42 (3), 586-602.

Gourlay, A. R., Pentecost, E. J., 2002. The determinants of technology diffusion: Evidence from the UK financial sector. Manchester School 70 (2), 185-203.

Griliches, Z., 1990. Patent statistics as economic indicators: A survey. Journal of Economic Literature 28 (4), 1661-1707.

Grossman, G. M., Helpman, E., 1994. Technology and trade. NBER Working Papers 4926, National Bureau of Economic Research, Inc.

Hannan, T. H., McDowell, J. M., 1984. The determinants of technology adoption: The case of the banking firm. Rand Journal of Economics 15 (3), 328-335.

Hashmi, A., 2007. Competition and innovation: The inverted-U relationship revisited. Working paper, University of Toronto.

Hauswald, R., Marquez, R., 2003. Information technology and financial services competition. Review of Financial Studies 16 (3), 921-948.

Hayami, Y., Ruttan, V. W., 1970. Agricultural productivity differences among countries. American Economic Review 60 (5), 895-911.

Hughes, J. P., Mester, L. J., 1993. A quality and risk-adjusted cost function for banks: Evidence on the "too-big-to-fail" doctrine. Journal of Productivity Analysis 4 (3), 293 315.

Humphrey, D. B., 1993. Cost and technical change: Effects from bank deregulation. Journal of Productivity Analysis 4 (1-2), 9-34.

Hunter, W. C., Timme, S. G., 1991. Technological change in large U.S. commercial banks. Journal of Business 64 (3), 339-362.

Ingham, H., Thompson, S., 1993. The adoption of new technology in financial services: The case of building societies. Economics of Innovation and New Technology 2, 263274.

Jones, K. D., Critchfield, T., 2005. Consolidation in the U.S. banking industry: Is the "long, strange trip" about to end? FDIC Banking Review 17(4), 31-61.

Kamien, M. I., Schwartz, N. L., 1982. Market Structure and Innovation. Cambridge University Press, New York, NY.

King, R. G., Levine, R., 1993. Finance and growth: Schumpeter might be right. Quarterly Journal of Economics 108 (3), 717-737.

Kroszner, R. S., Strahan, P. E., 1999. What drives deregulation? Economics and politics of the relaxation of bank branching restrictions. Quarterly Journal of Economics 114 (4), 1437-1467.

Krugman, P., 1986. A 'technology gap' model of international trade. In: Jungenfeldt, K., Hague, D. (Eds.), Structural Adjustment in Developed Open Economics. MacMillan Press, London, pp. 35-49. 
Kumbhakar, S. C., Lovell, C. A. K., 2000. Stochastic Frontier Analysis. Cambridge University Press, Cambridge, MA.

Lau, L. J., Yotopoulos, P. A., Oct. 1989. The meta-production function approach to technological change in world agriculture. Journal of Development Economics 31 (2), 241269.

Lerner, J., 2002. Where does "State Street" lead? A first look at finance patents, 1971-2000. The Journal of Finance 57 (2), 901-930.

Levin, R. C., W. M. C., Mowrey, D. C., 1985. R\&D appropriability, opportunity, and market structure: New evidence on some Schumpeterian hypotheses. American Economic Review 75 (2), 20-24.

Levine, R., 1997. Financial development and economic growth: Views and agenda. Journal of Economic Literature 35 (2), 688-726.

Levine, R., 2004. Finance and growth: Theory and evidence. National Bureau of Economic Research Working Paper Series No. 10766, -.

Levine, R., Loayza, N., Beck, T., 2000. Financial intermediation and growth: Causality and causes. Journal of Monetary Economics 46, 31-77.

Levine, R., Zervos, S., 1998. Stock markets, banks, and economic growth. American Economic Review 88 (3), 537-558.

Mantel, B., 2000. Why do consumers pay bills electronically? An empirical analysis. Federal Reserve Bank of Chicago Economic Perspectives , 4rth Quarter, 32-47.

Mantel, B., McHugh, T., 2001. Competition and innovation in the consumer payments market? Considering demand, supply, and public policy issues. Federal Reserve Bank of Chicago Emerging Markets Working Paper EPS-2001-4.

Miller, M., 1986. Financial innovation: The last twenty years and the next. Journal of Financial and Quantitative Analysis 21 (4), 459-471.

Molyneux, P., Shamoukh, N., 1996. Diffusion of financial innovations: The case of junk bonds and note issuance facilities. Journal of Money, Credit and Banking 28 (3), 502 522.

Mundlak, Y., Hellinghausen, R., 1982. The intercountry agricultural production function: Another view. American Journal of Agricultural Economics 62, 664-672.

Nickerson, D., Sullivan, R. J., 2003. Financial innovation, strategic real options, and endogenous competition: Theory and an application to internet banking. Federal Reserve Bank of Kansas City Payments System Research Working Paper PSR WP 03-01.

O'Donnell, C., Rao, D., Battese, G., 2008. Metafrontier frameworks for the study of firmlevel efficiencies and technology ratios. Empirical Economics 34 (2), 231-255.

Pagano, M., 1993. Financial markets and growth: An overview. European Economic Review 37(2-3), 613-622.

Pennings, J. M., Harianto, F., 1992. The diffusion of technological innovation in the commercial banking industry. Strategic Management Journal 13 (1), 29-46.

Pilloff, S. J., 1999. Multimarket contact in banking. Review of Industrial Organization 14 (2), 163-182.

Posner, M. V., 1961. International trade and technical change. Oxford Economic Papers 13 (3), 323-341.

Rhoades, S. A., 2000. Bank mergers and banking structure in the United States, 1980-98. In: Board of Governors of the Federal Reserve System. Vol. 174 of Staff Studies.

Ross, S. A., 1989. Institutional markets, financial marketing, and financial innovation. Journal of Finance 44 (3), 541-556. 
Saloner, G., Shepard, A., 1995. Adoption of technologies with network effects: An empirical examination of the adoption of automated teller machines. Rand Journal of Economics 26 (3), 479-501.

Scherer, F. M., 1967. Market structure and the employment of scientists and engineers. The American Economic Review 57 (3), 524-531.

Schumpeter, J. A., 1942. Capitalism, Socialism and Democracy. Harper and Row, New York, NY.

Stiroh, K. J., Strahan, P. E., 2003. Competitive dynamics of deregulation: Evidence from U.S. banking. Journal of Money, Credit and Banking 35 (5), 801-828.

Sullivan, R. J., 2000. How has the adoption of internet banking affected performance and risk in banks? Federal Reserve Bank of Kansas City Financial Industry Perspectives, $1-16$.

Symeonidis, G., 1996. Innovation, firm size and market structure: Schumpeterian hypotheses and some new themes. OECD Economics Department Working Paper 161.

Targetti, F., Foti, A., 1997. Growth and productivity: A model of cumulative growth and catching up. Cambridge Journal of Economics 21 (1), 27-43.

Tufano, P., 1989. Financial innovation and first mover advantages. Journal of Financial Economics 25 (2), 213-240.

Van Horne, J. C., 1985. Of financial innovations and excesses. Journal of Finance 40 (3), 620-631.

Vives, X., 2001. Competition in the changing world of banking. Oxford Review of Economic Policy 17 (4), 535-547.

Wheelock, D. C., Wilson, P. W., 1999. Technical progress, inefficiency, and productivity change in U.S. banking, 1984-1993. Journal of Money, Credit and Banking 31 (2), 212234.

White, L. J., 2000. Technological change, financial innovation, and financial regulation in the US: The challenges to public policy. In: Harker, P., Zenios, S. (Eds.), Performance of Financial Institutions: Efficiency, Innovation, Regulation. Cambridge University Press, Cambridge, MA, Ch. 11, pp. 388-415.

Wilhelm, W. J. J., 2001. The internet and financial market structure. Oxford Review of Economic Policy 17 (2), 235-247.

Windmeijer, F., 2005. A finite sample correction for the variance of linear efficient twostep GMM estimators. Journal of Econometrics 126 (1), 25-51. 